\title{
Õppimine ja väljalangemine IKT erialade esimesel aastal Eesti kõrgkoolide näitel
}

\author{
Külli Kori ${ }^{\mathrm{a}}$, Kadri Mardo \\ a Tartu Ülikooli haridusteaduste instituut \\ ${ }^{b}$ Tartu Katoliku Hariduskeskus
}

\begin{abstract}
Annotatsioon
Loodusteaduste ja tehnoloogia valdkonnas on suureks probleemiks üliõpilaste väljalangemine IKT erialadelt. Siinse kvalitatiivse uurimuse eesmärk on mõista sügavamalt erinevusi väljalangenud ja edasiõppivate üliõpilaste vahel ning leida abinõud, mida saaks väljalangemuse vähendamiseks kasutusele võtta. Andmeid koguti intervjuudega kaheksalt väljalangenud ja kaheksalt õpinguid jätkanud üliõpilaselt. Tulemused näitavad, et iseseisev IKT õppimine enne kõrgkooli muudab õpingud kõrgkoolis lihtsamaks ning õpingute jätkamisele aitab kaasa tugevam akadeemiline ja sotsiaalne integratsioon. Erinevused väljalangenud ja õpinguid jätkanud üliõpilaste vahel ilmnevad vaid akadeemilise integratsiooni puhul. Seevastu eri õppevormides õppivate üliõpilaste erinevused seisnevad varasemates kogemustes, kõrgkooli astumise eesmärkides, õpingutele pühendumises ja sotsiaalses integratsioonis. Tulemuste põhjal saab esitada soovitusi IKT erialadelt väljalangemise ennetamiseks.
\end{abstract}

Võtmesõnad: IKT, kõrgharidus, väljalangemine

\section{Sissejuhatus}

\section{Puudus IKT-oskustega inimestest}

Info- ja kommunikatsioonitehnoloogia (IKT) tähtsus eri elualadel on viimastel aastatel oluliselt kasvanud. Seetõttu on ka tööturul suurenenud nõudlus IKT-oskustega inimeste järele, eriti loodusteaduste ja tehnoloogia valdkonnas (Gareis et al., 2014). Prognoosid Euroopa Liidu kohta väidavad, et 2020. aastaks on puudu 481000 - 1685000 IKT-oskustega töötajat (Hüsing et al., 2013). Eesti kohta aga prognoositakse, et 2020. aastaks on 
vaja juurde 6661-8456 IKT-oskustega töötajat. Kui praegused vastuvõtuarvud kõrgkoolide IKT erialadel ei muutu, siis peaks 2020. aastaks olema kõrgkooli lõpetanud 8400 IKT-üliõpilast (Jürgenson et al., 2013), seega on nende arvude järgi Eestis nõudlus justkui täidetud. Siiski tekitab probleemi suur väljalangemine kõrgkoolidest, mistõttu jäävad paljud IKT valdkonna töökohtadest täitmata.

\section{Väljalangemine kõrgkoolist}

Kõrgkoolist väljalangemine on probleemiks kõikjal maailmas, seda nii IKT valdkonnas kui ka mujal. Euroopas on kõige kõrgem õpingute lõpetamise määr Taanis ja Suurbritannias, kus kooli lõpetab 80\% üliõpilastest, ning kõige madalam Ungaris ja Itaalias, kus õpingud lõpetab alla poole alustanutest (OECD, 2013). Kui vaadata õpingute valdkondi, siis enim langetakse välja loodusteaduse, matemaatika ja inseneriõppe valdkonnas (36-39\%) (Heublein, 2014), kuhu kuuluvad ka IKT erialad. Eesti kohta on samuti näidatud, et kõige enam katkestatakse õpinguid loodus- ja täppisteaduste valdkonnas, kõige vähem aga tervise- ja haridusvaldkonnas (Järve, Kallaste, \& Räis, 2015).

Euroopas langeb kõrgkoolist välja keskmiselt 19\% IKT-üliõpilastest (Hüsing et al., 2013). Eestis on IKT-üliõpilaste väljalangemus aga oluliselt suurem - kuni kaks kolmandikku üliõpilastest ei lõpeta kõrgkooliõpinguid. Seda on oluliselt rohkem kui teistel erialadel, kus keskmiselt katkestab õpingud 46,1\% üliõpilastest (arvutused EHIS, 2015 põhjal). Kõige suurem hulk üliõpilasi katkestab õpingud aga juba esimesel oppeaastal (Chen, 2012). Eesti hariduse infosüsteemi (EHIS) põhjal tehtud arvutused näitavad, et IKT valdkonnas on selliseid üliõpilasi $29,8 \%$, mis moodustab poole kõigist katkestajatest. Seevastu teistes valdkondades katkestab õpingud esimesel aastal keskmiselt 18\% üliõpilastest (arvutused EHIS, 2015 põhjal), mida on oluliselt vähem kui IKT erialadel. IKT erialadelt väljalangemise põhjuste uurimine on vajalik, sest uurimistulemuste põhjal saab kõrgkool kavandada ennetavaid sekkumismeetmeid. Siinses uurimuses püütakse välja selgitada, millised on IKT erialadelt väljalangemise põhjused ning mil viisil saaks vähendada IKT erialadelt väljalangemist. 


\section{Teoreetiline raamistik}

\section{Väljalangemine}

Tinto (1975) järgi saab väljalangemise uurimisel eristada kahte käsitlust. Nendest esimene võtab vaatluse alla üliõpilased, kes katkestavad oma õpingud kõrgkoolis ning kelle kohta pole teada, kas nad jätkavad kunagi hiljem õppimist samal või erineval õppekaval. Teine käsitlus hõlmab üliõpilasi, kes katkestavad oma õpingud kõrgkoolis ega omanda kunagi kõrgharidust. On arusaadav, et esimesel juhul kuulub kõrgkoolist väljalangejate hulka oluliselt rohkem üliõpilasi kui teisel juhul. Näiteks katkestas Austraalias tehtud uuringu kohaselt 20\% üliõpilastest õpingud, kuid vähem kui 10\% neist ei jätkanud kõrgkooliõpinguid edaspidi (Long, Ferrier, \& Heagney, 2006). Praegune uurimus põhineb esimesel käsitlusel - vaatluse all on üliõpilased, kes katkestavad oma õpingud, kuid pole teada, mis nendest üliõpilastest hiljem saab. Võib oletada, et paljud neist jätkavad õpinguid kas IKT valdkonnas või muul erialal ning osa neist võib IKT vallas jõuda ka tööturule.

Kõrgkoolist väljalangemine ei pruugi samas alati olla negatiivne. Kui üliõpilane ei olnud piisavalt võimekas, et kõrgkoolis hakkama saada, siis võib õpingute poolelijätmine olla mõistlik otsus. Õpingud katkestanud üliõpilasel võib sellest hoolimata olla varem kõrgkoolis läbitud õppeainetest oma hilisemates õpingutes kasu ning ta saab tulevasel töökohal kasutada oskusi, mille ta IKTd õppides omandas (Larsen, Kornbeck, Kristensen, Larsen, \& Sommersel, 2013). Näiteks on Jürgenson jt (2013) näidanud, et umbes 25\% Eesti IKT-töötajatest ei ole erialast haridust, samas kui teistes valdkondades on erialane haridus puudu vaid $10 \%$ töötajatest. Seega on tänu töökohtade rohkusele ka õpingud katkestanud üliõpilastel võimalik asuda IKT valdkonda tööle ning mitmed IKT-ettevõtted otsivad töötajaid õppivate üliõpilaste seast.

\section{Väljalangemist mõjutavad tegurid}

Kõrgkoolist väljalangemist on uuritud pikka aega. Kui varem tehti seda peamiselt psühholoogilisest vaatepunktist (üliõpilase individuaalsed omadused, oskused, motivatsioon), siis viimasel kümnendil on liigutud keerukama käsitluse juurde, mis hõlmab ka kõrgkooli ja selle keskkonna rolli (Tinto, 2006). See tähendab, et väljalangemine on kompleksne probleem, ning ka kirjandusest leiab väga palju erinevaid tegureid, mis mõjutavad kõrgkoolist väljalangemist. Näiteks on leitud, et üliõpilase sotsiodemograafiline taust (nt vanemate sissetulek) võib mõjutada üliõpilase väljalangemist (Chen, 2012), meessoost üliõpilastel on suurem risk kõrgkoolist välja langeda kui naistel 
(Belloc, Maruotti, \& Petrella, 2011), vanematel üliõpilastel on suurem risk kõrgkoolist välja langeda kui noorematel (Lassibille \& Gómez, 2008) ning gümnaasiumis paremaid hindeid saanud õpilased on kõrgkoolis väiksema väljalangemisriskiga (Belloc et al., 2011). Ka institutsionaalsed tegurid, nagu üliõpilaste demograafiline taust (nt vähemusrahvuste osakaal üliõpilaste hulgas), kõrgkooli struktuur, teaduskonna ressursid ja rahaline olukord, võivad mõjutada väljalangemist (Chen, 2012).

Põhjalikumalt on kõrgkoolist väljalangemist uurinud Larsen ja tema kolleegid (2013), kes tõid süstemaatilise kirjandusanalüüsi põhjal välja 11 väljalangemist mõjutavat tegurit: 1) üliõpilase sotsiodemograafiline taust (sh vanemate haridustase, sissetulek), 2) akadeemilised pädevused/eeldused õppimiseks, 3) ettevalmistus õppimiseks (sh sobiva õppekava valik, õpingutele seatud ootused), 4) motivatsioon õppimiseks, 5) strateegiad, mida õppimisel kasutatakse, 6) õppetingimused (sh õppekava, õpingute koormus, õppejõud, füüsiline ja vaimne kliima), 7) sotsiaalne ja/või akadeemiline integratsioon kõrgkoolis, kohanemine kõrgkooliga, 8) üldine hinnang kõrgkoolielule, 9) väljalangejate võimalused väljaspool kõrgkooli (nt töövõimalused), 10) üliõpilase majanduslik olukord (sh õppemaksu maksmine, stipendiumi saamine) ning 11) üliõpilase elamistingimused (isiklik olukord, pere olukord ja toetus ning töötamine õpingute ajal). Ka teistes uurimustes (nt Wolter, Diem, \& Messer, 2014) on leitud, et väljalangemist mõjutavad tegurid on väga sarnased Larseni jt (2013) nimetatud teguritega.

Eeltoodud väljalangemist mõjutavad tegurid ei näita aga nende omavahelisi seoseid ning seetõttu annab väljalangemise mudel olukorrast terviklikuma pildi. Ühe tuntuima väljalangemise mudeli on koostanud Vincent Tinto (1993). Tinto integratsioonimudel näitab, et väljalangemine on dünaamiline protsess, mida mõjutab kõrgkooli ja üliõpilaste integratsioon akadeemilises ja sotsiaalses kontekstis. Mudelis eristatakse tegureid, mis on avaldanud õppijale mõju enne kõrgkooli (pere taust, oskused, varasem õppimine), kõrgkooli astumise eesmärke ja pühendumist ning kõrgkooliga seotud institutsionaalset kogemust, mis jaguneb akadeemiliseks ja sotsiaalseks integratsiooniks (vt joonis 1). Tinto (1993) mudelis eristatakse kahte tüüpi pühendumist: esimene neist on seotud kõrgkooli sisseastumisega, teine aga kõrgkoolis õppimise kogemusega, mis mõjutab otseselt üliõpilase otsust, kas jätkata õpinguid või mitte. 


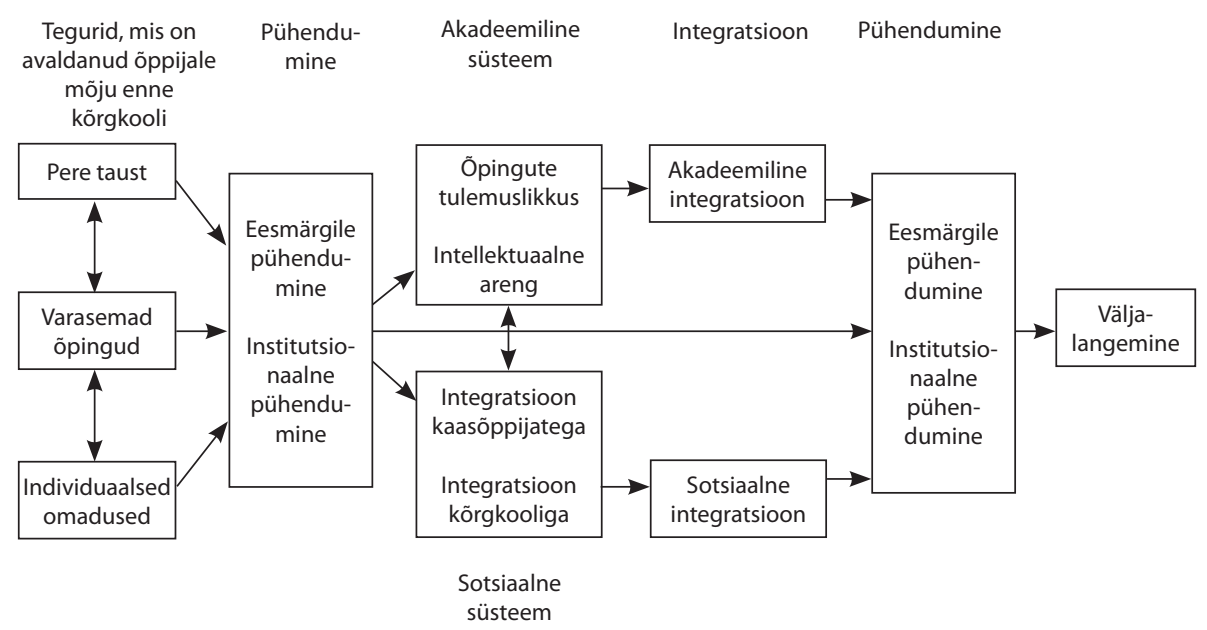

Joonis 1. Tinto integratsioonimudel (1993, lk 114)

Tinto mudelile tuginedes on akadeemilise integratsiooni kohta leitud, et halvemate õpitulemustega üliõpilased langevad suurema tõenäosusega kõrgkoolist välja (Belloc et al., 2011; Stratton, O’Toole, \& Wetzel, 2008) ning väljalangemisega on kõige tugevamini seotud üliõpilase keskmine hinne (Chen, 2012). Sotsiaalse integratsiooniga seoses on täheldatud, et üliõpilased, kes suhtlevad kaasüliõpilaste ja õppejõududega rohkem ning veedavad rohkem aega kõrgkooli linnakus ja osalevad üliõpilasorganisatsioonide tegevuses, lõpetavad õpingud suurema tõenäosusega kui need üliõpilased, kelle sotsiaalne integratsioon kõrgkoolis on nõrgem (Chen, 2012; Duque, 2014). Kuigi mitmed autorid on leidnud, et Tinto varasem teoreetiline mudel (1975) sobib väljalangemise uurimiseks (nt Terenzini \& Pascarella, 1980), kasutatakse siinses uurimuses Tinto mudeli edasiarendust (Tinto, 1993). Samas on uurimusi, kus kritiseeritakse Tinto mudelit näiteks seetõttu, et see ei sobivat vähemusrahvuste ja ebatraditsiooniliste üliõpilaste jaoks, kelle puhul on väljalangemisel olulised ka kõrgkoolivälised tegurid (Hurtado \& Carter, 1997).

Teise tuntuima väljalangemise mudeli on koostanud John P. Bean (1985). Sellel mudelil on mitmeid sarnasusi Tinto mudeliga ning neid kahte mudelit on ka omavahel kombineeritud (vt Cabrera, Nora, \& Castaneda, 1993). Peamine erinevus mudelite vahel seisneb selles, et Beani mudelisse on kaasatud välised tegurid (nt sõprade ja pere toetus, finantsolukord), mis pole otseselt seotud kõrgkooliga, kuid mis mõjutavad üliõpilaste hoiakuid ja otsuseid (Cabrera et al., 1993). Siinses uurimuses soovitakse aga jääda kõrgkoolikeskseks ja esitada soovitusi selle kohta, mida saaks kõrgkool teha 
üliõpilaste väljalangemuse vähendamiseks. Kõrgkoolieelsetest kogemustest on aga vaatluse all vaid varasemad õpingud. Selle mudeli alusel uuritakse, millised tunnused iseloomustavad õppivaid ja õpingud katkestanud IKTüliõpilasi.

\section{IKT erialade spetsiifika}

Eelnimetatud uurimustes on vaadeldud kõrgkoolist väljalangemist eri valdkondades. IKT valdkonnas võib väljalangemisel olla aga oma spetsiifika, sest IKT valdkond areneb väga kiiresti. Samuti iseloomustab IKT erialasid suurem väljalangemus kui teistel erialadel. Siiski on IKT erialadelt väljalangemist uuritud üsna vähe.

Üks põhjuseid, miks kõrgkoolist välja langetakse, on vale erialavalik või valed ootused eriala suhtes (Foster et al., 2012; Järve et al., 2015). On leitud, et IKT valdkonnas ootavad üliõpilased tihti praktilisemat ainekäsitlust, kuid õpingute esimestel semestritel keskendutakse pigem teoreetilistele õppeainetele. Praktilisemat õpet pakutakse aga rakenduskõrghariduses ja kutsehariduses, mis võivad IKT-üliõpilaste ootustele tihti paremini vastata (Järve et al., 2015).

Valele erialavalikule võib viidata see, kui üliõpilased ei tule õpingutega toime. IKT-õpingute alguses tuleb üliõpilastel läbida suures mahus matemaatika ja programmeerimisega seotud óppeaineid, mis on neile keerulised. Horvaatias tehtud uuring näitab, et sissejuhatava matemaatikakursuse läbib esimesel semestril vaid 60,56\% IKT-üliõpilastest (Divjak, Ostroski, \& Hains, 2010). Sissejuhatavate programmeerimiskursuste kohta on süstemaatilise kirjandusanalüüsi põhjal leitud, et need läbib vaid 67,7\% üliõpilastest (Watson \& Li, 2014). Kui sissejuhatavad õppeained on üliõpilaste jaoks liiga keerulised, siis on tõenäoline, et nad ei taha õpinguid sellel erialal jätkata (Baker, McDowell, \& Kalahar, 2009).

Teadlikku erialavalikut võib soodustada varasem kogemus programmeerimise õppimisel - kas formaalõppes või iseseisvalt. On leitud, et varasema programmeerimiskogemusega üliópilased saavutavad paremaid õpitulemusi (Hagan \& Markham, 2000) ja hindavad õpinguid kõrgkoolis lihtsamaks kui varasema programmeerimiskogemuseta üliõpilased (Kori, Pedaste, Leijen, \& Tõnisson, 2016). Seega võivad IKT-õpingud keeruliste programmeerimise ja matemaatika õppeainete tõttu pooleli jätta just need üliõpilased, kellel puuduvad programmeerimiskogemused.

Kui aga erialavalik on õige ja raskusi õppimisega pole, siis võib väljalangemist soodustada töökohustuste võtmine õpingute ajal, mistõttu pole üliõpilasel piisavalt aega õpingutele pühenduda. IKT valdkonna eripära 
on see, et töökohtade rohkuse tõttu lähevad paljud üliõpilased õpingute ajal tööle. Seetõttu jääb üliõpilasel vähem aega õppimiseks ning see võib samuti põhjustada kõrgkoolist väljalangemist (Taylor, Lekes, Gagnon, Kwan, \& Koestner, 2012). On leitud, et mida suurema koormusega üliõpilane töötab, seda suurem on tema väljalangemise tõenäosus (Polidano \& Zakirova, 2011). Töötamisvajaduse vähendamiseks on IKT valdkonna üliõpilastele Eestis loodud mitmeid võimalusi saada lisastipendiumit. Samas ei ole see sissetulek võrreldav töökohtadel saadava palgaga. Uurimused on siiski näidanud, et stipendiumi ja teiste rahaliste toetuste saamine suurendab tõenäosust, et üliõpilane lõpetab õpingud (Chen, 2012).

Artikli uurimisprobleem on asjaolu, et pole täpselt teada, mis tegurid mõjutavad üliõpilaste väljalangemist IKT erialadelt ning mida saaks selle vähendamiseks ette võtta. Uurimuse aluseks on võetud Tinto (1993) integratsioonimudeli tegurid: tegurid, mis on avaldanud õppijale mõju enne kõrgkooli (sh varasemad õpingud), eesmärgid, pühendumine, akadeemiline ja sotsiaalne integratsioon. Uurimisprobleemist lähtuvalt on artikli eesmärk mõista Eesti näitel sügavamalt erinevusi väljalangenud ja edasiõppivate üliõpilaste vahel ning leida, mida saaks väljalangemise vähendamiseks ette võtta.

Eesmärgist lähtudes püstitatakse järgmised uurimisküsimused.

1. Mis tunnused iseloomustavad IKT erialadel esimesel aastal õpingud katkestanud ja mittekatkestanud üliõpilasi?

2. Mille poolest erinevad IKT erialadel esimesel aastal õpingud katkestanud üliõpilased mittekatkestanud üliõpilastest?

3. Kuidas saaks üliõpilaste arvates vähendada väljalangemist IKT erialadelt?

\section{Metoodika}

\section{Valim}

Siinses uurimuses kasutatakse kvalitatiivset uurimismeetodit, et uurida sügavuti õpingud katkestanud ja õpinguid jätkanud üliõpilaste arvamusi. Uurimuse raames tehti 16 poolstruktureeritud intervjuud üliõpilastega, kes olid asunud 2014. aasta kevadel õppima kahe Eesti kõrgkooli IKT esimese õppeastme õppekavadel. Eestis on kokku seitse kõrgkooli, kus õpetatakse IKT-üliõpilasi, ning nendest valiti mugavusvalimi alusel välja kaks kõrgkooli, mille üliõpilased kaasati uuringusse. Pooled intervjueeritavatest olid esimesel õppeaastal kõrgkoolist välja langenud ning pooled jätkasid samal erialal õppimist järgmisel õppeaastal (teisel kursusel). Lisaks kaasati valimisse üliõpilasi võimalikult erinevatest õppevormidest (päevane õpe, 
õhtune õpe, kaugõpe). Valimisse kuulunud kahest kõrgkoolist küsiti informatsiooni üliõpilaste edasijõudmise kohta (kes langesid esimesel õppeaastal või teise õppeaasta alguses kõrgkoolist välja ja kes jätkavad õpinguid) ning üliõpilaste e-posti aadresse. Kriteeriumitele vastanud kandidaatidega kontakteeruti e-posti vahendusel. Kokku saadeti e-posti teel 109 ettepanekut intervjuus osalemiseks. Vastus saadi 16 inimeselt (tabel 1). Kuna vastajate hulgas oli rohkem naissoost üliõpilasi, moodustasid nad seetõttu poole valimist, kuigi naisi on IKT erialadel vaid umbes $25 \%$ (Kori et al., 2015). Lisaks vastas ühest kõrgkoolist rohkem üliõpilasi, kes seepärast moodustasid valimist 75\%. Vastajate keskmine vanus oli 24 eluaastat, mis on kõrgem kui IKT erialadel üldiselt (Kori, Altin, Pedaste, Palts, \& Tõnisson, 2014). Seega ei esinda kvalitatiivse uuringu valim soolise ja vanuselise jaotuse poolest kõiki Eesti IKT-üliõpilasi.

Tabel 1. Valimisse kuulunud intervjueeritavad

\begin{tabular}{|c|c|c|c|c|c|}
\hline Intervjueeritav & Sugu & Vanus & Õppevorm & Õpingute kestus & Töötamine \\
\hline V1 & $\mathrm{N}$ & 28 & õhtune õpe & 4 kuud 30 päeva & jah \\
\hline V2 & $\mathrm{N}$ & 19 & päevane õpe & 9 kuud 17 päeva & ei \\
\hline V3 & M & 20 & päevane õpe & 9 kuud 7 päeva & ei \\
\hline V4 & $\mathrm{N}$ & 32 & kaugõpe & 3 kuud 15 päeva & ei \\
\hline V5 & $\mathrm{N}$ & 26 & õhtune õpe & 4 kuud 29 päeva & jah \\
\hline V6 & $M$ & 25 & kaugõpe & 7 kuud 14 päeva & jah \\
\hline V7 & $\mathrm{N}$ & 20 & päevane õpe & 10 kuud 6 päeva & ei \\
\hline V8 & M & 20 & päevane õpe & 1 aasta 26 päeva & ei \\
\hline Ü1 & $M$ & 21 & päevane õpe & 1 aasta 6 kuud & ei \\
\hline Ü2 & M & 21 & päevane õpe & 1 aasta 6 kuud & jah \\
\hline Ü3 & M & 21 & päevane õpe & 1 aasta 6 kuud & jah \\
\hline Ü4 & $\mathrm{N}$ & 27 & õhtune õpe & 1 aasta 6 kuud & jah \\
\hline Ü5 & $\mathrm{N}$ & 32 & kaugõpe & 1 aasta 6 kuud & jah \\
\hline Ü6 & M & 31 & kaugõpe & 1 aasta 6 kuud & jah \\
\hline Ü7 & $\mathrm{N}$ & 27 & õhtune õpe & 1 aasta 6 kuud & jah \\
\hline Ü8 & $M$ & 24 & päevane õpe & 1 aasta 6 kuud & jah \\
\hline
\end{tabular}

Märkus. N - naine; M - mees; V - väljalangenud; Ü - õppiv üliõpilane. 


\section{Andmekogumine}

Andmeid koguti poolstruktureeritud intervjuuga. Intervjuu küsimused koostati Tinto (1993) integratsioonimudeli põhjal. See tähendab, et küsiti küsimusi kõrgkoolile eelnevate õpingute, kõrgkooli astumise eesmärkide, õpingutele pühendumise ning akadeemilise ja sotsiaalse (suhted kaasõppijate ja õppejõududega) integratsiooni kohta. Intervjuu kava on esitatud artikli lisas. Esialgsete küsimuste arusaadavust hinnati prooviintervjuudega, mille tulemusena olulisi muudatusi küsimustes ei tehtud. Nii óppivate kui ka väljalangenud üliõpilaste intervjueerimisel kasutati samu küsimusi, kuid óppivate üliõpilaste küsimuste seast eemaldati väljalangemisega seotud küsimused.

Intervjuu keskmine pikkus oli 26 minutit. Kõige lühem intervjuu kestis 14 minutit ja pikim 46 minutit. Intervjuud toimusid kohapeal või elektrooniliselt programmi Skype vahendusel. Intervjuud salvestati edasiseks analüüsiks ja transkribeeriti täies mahus. Konfidentsiaalsuse tagamiseks varustati intervjueeritavad koodidega Üx ja Vx, kus Ü tähistab üliópilast ja V väljalangenut (tabel 1).

\section{Andmeanalüïs}

Intervjuude analüüsimiseks kasutati induktiivset sisuanalüüsi. Nimelt võimaldab induktiivne sisuanalüüs sügavamalt mõista intervjueeritavate kogemusi ja tõlgendusi ning mitte piirata nende vastuste analüüsimist teooriaga. Esmalt loeti transkriptsioonid korduvalt läbi ja märgiti ära uurimisküsimuste seisukohast tähendusrikkad fraasid. Seejärel moodustati tähendusrikastest fraasidest lühemad lausungid, mis koondati lausungi põhjal loodud märksõna ehk koodi alla. Viimased ühendati sarnase sisu alusel alamkategooriateks, millest omakorda moodustati kategooriad. Alljärgnevalt on esitatud üks näide kategooriate loomise kohta:

- tähendusrikas fraas - /.../ aga ma ei jõudnud mitte kunagi nagu midagi juurde óppida ega nagu paremini aru saada;

- lausung - ei jõudnud lisaks óppida ja aru saada;

- kood - óppimine ajamahukas;

- alamkategooria - ajaressurss;

- kategooria - ópingute katkestamise põhjused.

Nii jagati näiteks üliõpilaste vastused õpingute katkestamise põhjuste kohta induktiivselt viieks alamkategooriaks: ajaressurss, vale eriala, huvi kadumine, rahalised probleemid ja logistilised probleemid. Kategooriatele ja alamkategooriatele lisati numbrilised väärtused. Usaldusväärsuse suurendamiseks kaasati kodeerimisse ka teine kodeerija: mõlemad kodeerisid 
neli intervjuud ja arutasid kategooriad omavahel läbi, seejärel arvutati hindajatevahelise usaldusväärsuse näitaja Coheni kapa väärtus (Cohen, 1960). Coheni kapa väärtus oli 0,8, mis näitab head kokkulangevust kahe hindaja vahel (Landis \& Koch, 1977).

Siinses artiklis on induktiivselt tekkinud kategooriad paigutatud Tinto (1993) mudelisse ning tulemused esitatakse süsteemselt mudelis välja toodud kategooriate kaupa.

\section{Tulemused}

\section{Kõrgkoolile eelnevad IKT õppimise kogemused}

Üliõpilaste varasemad IKT õppimise kogemused jagati järgmistesse alamkategooriatesse: üldhariduskoolis óppimine, lisakursustel osalemine, iseseisev õppimine, tööl õppimine. Kõik uuringusse kaasatud üliõpilased olid osalenud üldhariduskooli mingis astmes arvutiõpetuse või informaatikatundides ja saanud arvutitega töötamise kogemuse. Varasemate IKT õppimise kogemustes esines mõningaid erinevusi väljalangenud ja õpinguid jätkanud üliõpilaste vahel. Uuringus osalenute sõnul tegeleti arvutiõpetuse või informaatikatundides peamiselt erinevate teksti- ja pilditöötlusprogrammidega, õpiti koostama esitlusi ja vähesel määral tutvustati mõnes koolis ka algtasemel programmeerimist. Intervjuude tulemused näitavad, et enamasti õppisid huvilised noored IKTd iseseisvalt. Leidus ka selliseid üliõpilasi, kes olid osalenud mitmesugustel lisakursustel juba gümnaasiumi ajal. Nende huvi IKT vastu tekkis varakult, mis mõjutas ka edasist erialavalikut kõrgkoolis. Siinkohal eristusid teistest aga kaugõppe üliõpilased, kelle huvi IKT vastu tekkis esialgsel töökohal, see aga mõjutas õpingute alustamist. Kaks vastajat tõid ka välja, et tahaksid tulevikus siduda IKT oma varem õpitud erialaga, nt juuraga.

Noo tööga ja ka tegelikult nooo IT selles mõttes, et hobi mõttes on see ka alati olnud. Olen siin tuttavatele mingit itipoissi mänginud mingil tasemel /.../ Ma pole kunagi seda ITd óppinud. Kõik, mida ma tean, on selline eneseharimise ja kogemuse asi. (Ü6)

Üldhariduskoolis läbitud arvutiõpetuse või informaatikatunnid ei andnud üliõpilaste endi arvates neile kõrgkoolis õppimisel eelist. Küll aga tundsid need, kes olid varem iseseisvalt IKTd õppinud, et varasem õppimine tuli vahel kõrgkoolis kasuks. Negatiivsena tuli välja, et vastajate seas oli ka selliseid üliõpilasi, kellel polnud gümnaasiumis võimalik õppida informaatikat isegi siis, kui huvi valdkonna vastu oli olemas. Üliõpilaste arvates tuleks 
kõigile õpilastele anda üldhariduskoolis võimalus IKTd õppida, sest see ühtlustaks kõrgkooli astuvate üliõpilaste varasemaid teadmisi ja oskusi.

\section{Kõrgkooli astumine}

IKT-üliõpilaste kõrgkooli astumise eesmärgid jagati järgmistesse alamkategooriatesse: erialaste oskuste/teadmiste omandamine, ettevõtluseks vajaliku oskuste omandamine, rohke programmeerimise õppimine, vähene programmeerimise õppimine. Üldiselt olid üliõpilaste ootused väga erinevad. Oodati, et programmeerimisaineid oleks kas palju või hoopiski vähe, samuti eeldati rohkem suhtlemist, praktilisi tegevusi ja IKTst üldpildi omandamist. Siiski ei eristunud väljalangenud ja õpinguid jätkanud üliõpilased oma ootuste poolest. Samuti leidsid nii väljalangenud kui ka õpinguid jätkanud üliõpilased, et õpingud ei vastanud nende esialgsetele ootustele. Väljalangenute hulgas oli ka neid, kes vastasid, et nad lausa pettusid õpingutes. Nende arvates sai õpingute ajal teha liiga vähe praktilist tööd ja tihtipeale olid seminarirühmades eri tasemega üliõpilased, mistõttu oli õppejõul keeruline valida seminari töötempot. Õpinguid jätkanud üliõpilaste arvates ei vastanud küll õpingud nende esialgsetele ootustele, kuid õppeained olid ikkagi vajalikud ja huvitavad ning nad kohanesid õpingutega ja nende ootused eriala suhtes muutusid edasiste õpingute käigus positiivsemaks.

Üliõpilaste vastused enne õpinguid õppekavaga tutvumise kohta jagati järgmistesse alamkategooriatesse: õppekava kirjelduste lugemine, ainete sisukirjelduste lugemine, tunniplaaniga tutvumine, kõrgkoolis ekskursioonil käimine ja lisainformatsiooni otsimine. Intervjuudest ilmnes, et suur osa üliõpilastest tutvus enne kõrgkooli astumist õppekavaga vaid pinnapealselt ega saanud sellest hästi aru. Samas oli aga ka neid üliõpilasi, kes olid soovitud IKT eriala kohta põhjalikku teavet kogunud, ning üliõpilasi, kes uurisid õppekavasid sellepärast, et leida endale sobivaim õppevorm (nt kaugõpe), mida ei pakuta kõikides kõrgkoolides. Üliõpilased leidsid ka, et reklaamid annavad praegu erialast liiga üldise pildi ja õppima tulevad üliõpilased ei tea, mida IKT õppimine tegelikult tähendab. Seega oleks üliõpilaste arvates hea, kui juba gümnaasiumis oleks õpilastel selge arusaam, mida kujutab endast IKT óppimine ja kas see eriala sobib neile. Sisseastujate motivatsiooni määramiseks võiksid intervjueeritavate arvates olla kõrgkoolides testid või vestlused, mis näitaksid, millised on kandidaadi teadmised ja motivatsioon IKT valdkonnas.

Nt mõni, kes jäi pingereast välja, aga tema motivatsioon oleks suurem olnud võib-olla, siis ta oleks ehk edukam olnud ITs kui mina, kes ma välja läksin. /.../ Oluline on see, et ülikool oleks huvitatud persoonist, mitte numbrist. (V7) 


\section{Õpingutele pühendumine}

IKT-üliõpilaste hulgas oli nii neid, kes töötasid õpingute ajal, kui ka neid, kes ei töötanud. Töötavaid üliõpilasi oli rohkem õhtuse ja kaugõppe üliõpilaste seas (7 üliõpilast 8st) kui päevases õppes õppivate üliõpilaste seas (3 üliõpilast 8st). Erinevused õpingutele pühendumises ilmnesidki peamiselt eri õppevormide vahel. Päevase õppe üliõpilased ei leidnud aega päeval tööl käimiseks, kuid õhtuse või kaugõppe üliõpilased käisid pigem nädala sees päeval tööl ning õppisid õhtuti ja nädalalavahetustel.

Õpingute ajal töötamise põhjused jagati järgmistesse alamkategooriatesse: majanduslik põhjus, kogemuse saamine ja varasemal töökohal jätkamine. Teisel õppeaastal õpinguid jätkanud üliõpilased asusid õpingute kõrvalt tööle eelkõige majandusliku olukorra parandamiseks. Lisaks oli neile oluline praktiline töökogemus. Intervjueeritavad nentisid, et kõrgkoolis jääb tihti praktikast puudu ja töötamine aitab neil oma oskusi praktiseerida. Üliõpilased leidsid, et kõrghariduskraad on tööturul pigem usaldusväärsuse ja järjepidevuse näitaja ega väljenda seda, mida töötaja tegelikult oskab. Arvati, et palka kõrgharidus eriti ei mõjuta.

Tegelt tööandjad hindavad pigem seda kogemust rohkem, et ma isegi ei tea, et diplom oleks kasuks mulle. See pigem näitab, et ma olen selle värgi läbi teinud /.../ et see on pigem mulle endale kinnitus. (V2)

Intervjuudest jäi kõlama, et õpingute lõpetamine ei ole üliõpilaste jaoks kuigi oluline ja pigem tasub kohe tööle minna. Samuti toodi välja, et kõrgkoolis sisendatakse esmakursuslastele, et diplomit pole tegelikult tööturule sisenemisel vaja. Vastukaaluks tõid aga õhtuse ja kaugõppe üliõpilased näiteid, et nendega koos õpib ka IKT-üliõpilasi, kellel on aastatepikkune IKT valdkonnas töötamise kogemus ja kes vajavad kraadi, et karjääriredelil tõusta.

Meie kursusel on paljud, kes on töötanud aastaid juba IT valdkonnas, neil on koolis hästi lihtne, aga siis teised küsisidki, et „Miks te tulete? Te juba oskate!“ /.../ Et ikkagi see paber või sertifikaat võib-olla Eestis väga ei loe, aga rahvusvaheliselt ma olen aru saanud, et see paber ikkagi loeb. (Ü5)

Stipendiumite kohta ütlesid intervjueeritavad, et need on pigem lisaväärtuseks ning ei mõjuta kuidagi õpimotivatsiooni. Kui IKT-üliõpilastelt intervjuudes küsiti, kui suur peaks olema saadav stipendium, erinesid vastused õppevormide vahel. Päevase õppe üliõpilased pidasid piisavaks summaks 300-400 eurot kuus, samas õhtuse ja kaugõppe üliõpilased tõid sobiva igakuise stipendiumi suurusena välja 430-1065 euro suuruseid summasid. 
Ma arvan, et kui väga vaja, siis nt 400 eurot oleks umbes siuke summa, millega saaks hakkama vajadusel, ilma et peaks kuskil tööl käima. Kui väga vaja ... aga see oleks siuke kiirnuudlite söömine. (Ü8)

Intervjuudes eristusid teistest väljalangenud kaugõppe üliõpilased, kes ei saanud õpingute ajal stipendiumit. Stipendiumi mittesaamise põhjusena nimetati peamiselt liiga lühikest õpingute kestust, mille tõttu ei saanud stipendiumit taotleda. Lisaks määrati esimesel semestril stipendiume gümnaasiumi riigieksamite tulemuste põhjal, mis omakorda piiras stipendiumi saajate hulka - seda just kaugõppes, kus oli inimesi, kellel jäid gümnaasiumi lõpus vajalikud eksamid tegemata või kelle tulemused ei olnud piisavalt head. Seepärast leidsid vastajad, et stipendiume peaks jagatama vajaduse põhjal. Stipendium oleks intervjueeritavate jaoks piisavalt motiveeriv, kui see võimaldaks õppida stressi- ja pingevabalt.

Ma ei pea nii palju pingutama, et saada seda raha üldse, aga samas ma saan seda õppida, omandada selle nii ideaalsel määral, aga teengi halvemate hinnete peale. Oleksin õnnelikum ja ei pea nagu vaeva nägema selle jaoks. (V2)

Stipendiumi saamisel ilmnes ka erinevus õppivate ja väljalangenud üliõpilaste vahel. Väljalangenud üliõpilastest said stipendiume enamasti vaid päevase õppe üliõpilased, kuid õpinguid jätkanud üliõpilased said stipendiumi kõikides õppevormides. Teisel õppeaastal õpinguid jätkanud üliõpilased osutasid, et suure väljalangemuse tõttu väheneb esimesel aastal üliõpilaste arv, seega makstakse stipendiume peaaegu kõikidele teise aasta üliõpilastele.

\section{Akadeemiline integratsioon}

Siinses artiklis vaadeldakse akadeemilise integratsiooni all ópingutega hakkama saamist ja õpingute tulemuslikkust. Üliõpilaste vastused õppejõudude õppemeetodite kohta, mis neile kõige enam sobisid, jagati järgmistesse kategooriatesse: praktikumid/seminarid, videoloengud, teooria ja praktika kooskõla, arutelud. Intervjuud näitasid, et teooriakesksed õpingud ei ole IKT-üliõpilaste hinnangul kuigi kasulikud, mistõttu eelistatakse rohkem praktilisi õppeaineid, kus saab ise ülesandeid ja probleeme lahendada. Üldiselt meeldisid üliõpilastele need õppeained, mis olid üles ehitatud iganädalasele loengule ja praktikumile, kus käsitleti loengu teemat praktilisemalt. Siiski toodi probleemina välja, et kõrgkoolid kasutavad tihtilugu vanemate kursuste üliõpilasi praktikumijuhendajatena ja nende pädevus teema õpetamisel polnud IKT erialade esmakursuslastele alati piisav. 
Ja siis õpetaja [praktikumijuhendaja] oli umbes nii: „A vot teate, proovime seda teha vot niimoodi. Ei ... niimoodi ei lähe. Oodake, siin on see viga. Aaa ... miks see ei tööta?" Siis ta tegi pausi kümneks minutiks ja naases „Aaa ... siin peab see niimoodi olema!“ ja see tekitas täielikku segadust. (V4)

Peale selle väärtustas suur osa IKT-üliõpilastest videoloenguid. Video vaatamise võimalusi kasutasid nii õhtuse ja kaugõppe kui ka päevase õppe üliõpilased, kes loengus kohal ei käinud. Videoloengu eelisena toodi ka välja, et loengu kuulamise tempot saab ise reguleerida, videot saab pausi peale panna ja tagasi kerida, kui midagi jäi arusaamatuks. Siiski osutati ka probleemidele, mis on seotud video kvaliteedi ja suure mahuga.

Videoloengud on seepärast head, et laed alla ära ja siis saad neid kiiremini vaadata. Ma ei pea tund ja pool raiskama selle peale, et õppejõud räägib aeglaselt. (Ü1)

Peamine õppemeetod, mis intervjueeritud üliõpilastele raskusi valmistas, oli auditoorne loeng. Probleemidena toodi välja, et õppejõud loevad loengutes tihti konspekti slaididelt maha ja mõned õppejõud ei taha õppematerjale üliõpilastega iseseisvaks õppimiseks jagada, kuigi loengus saadud seletustest üliõpilased esimesel korral aru ei saanud.

Mõned on nagu natuke kiuslikud, et nad ei pane materjale üles, või siis teevadki nii, et mingid tõestused on, aga mida nad ei pane slaididele üles ja samas kirjutab kribu teksti suure audika tahvlile, et sa ei näe midagi ja ei saa aru. (V2)

Üliõpilaste vastused probleeme tekitavate õppeainete kohta jagati järgmistesse alamkategooriatesse: programmeerimine, algebra, füüsika, probleeme tekitavad õppeained puuduvad. Intervjuudest selgus, et üliõpilastel oli probleeme konkreetsete õppeainetega, eriti programmeerimisega. Nad tundsid, et programmeerimise õppeainetes ei arvestata õppijate eri tasemetega. Siiski oli näha erinevusi nende üliõpilaste vahel, kes esimesel aastal õpingud katkestasid, ja nende vahel, kes õpinguid teisel aastal jätkasid. Õpingud katkestanud üliõpilased nimetasid raskustena peamiselt keerulisi programmeerimisaineid, kuid õpinguid jätkanud üliõpilaste arvates olid keerulised pigem loogika, algoritmide ja matemaatikaga seotud õppeained. Erinevalt õpingud katkestanud üliõpilastest leidsid õpinguid jätkanud üliõpilased, et alusained olid õppekavasse sobilikud ning järgnevatel õppeaastatel on õppeained spetsiifilisemad, praktilisemad ja huvitavamad.

Intervjueeritavad mainisid, et kõrgkoolis võiks olla rohkem tugiteenuseid, näiteks mentori- ja tuutoriprogrammid, kus saab vanema kursuse 
üliõpilase käest õppetöös abi küsida. Kasuks tuleksid ka konsultatsiooniajad, mis on tunniplaani kavandatud ja mille ajal saab õppejõult abi küsima minna. Samuti arvasid üliõpilased, et aitaks see, kui nad oleksid õppeainetes oma taseme järgi gruppidesse jagatud.

\section{Sotsiaalne integratsioon}

Suhted kaasüliõpilastega jagati intervjuude põhjal järgmistesse alamkategooriatesse: üksteise abistamine, rühmatööde tegemine, neutraalsed suhted, kauged suhted ja liiga suur kursus. Suhted õppejõududega jagunesid järgmistesse alamkategooriatesse: head suhted, kauged suhted ja õppejõudude ebapädevus. Erinevus ilmnes kaugõppe ja päevase õppe üliõpilaste vahel. Nimelt vastasid kaugõppe üliõpilased, et nad suhtlevad teiste IKT-üliõpilaste ja õppejõududega vähem kui päevase õppe üliõpilased. Üldiselt kiitsid kõik IKT-üliõpilased oma õppejõude, sest nad olid abivalmid ja paindlikud. Siiski leiti, et on ka neid õppejõude, kelle suhtumine valmistab üliõpilastele ebameeldivusi. Sellised õppejõud olid tavaliselt kas õppejõudude asendajad või vanema kursuse üliõpilased.

Ta [praktikumijuhataja] on muidu hästi tore ja lahe, aga äärmiselt kõrk ja nimetaski klassi ees „Need, kes seda ei tea, on lihtsalt lollid!“. / . . . Hästi palju probleeme tekitas ka see, et ei saanud küsida lolle küsimusi. /.../ siis tekkiski nii rumal tunne ja ei lähegi kellegi käest uurima. (V2)

Ka teiste IKT-üliõpilastega suhtlemise kohta ilmnes uuringus osalenud üliõpilaste vastustest, et rohkem suhtlevad omavahel päevase õppe üliõpilased. Päevases õppes näevad üliõpilased üksteist iga päev, kuid kaugõppes kohtutakse vaid korra kuus. Üks väljalangenud üliõpilane tõi aga suhtlemise puhul negatiivsena välja asjaolu, et kõrgkooli astudes said tema elu suureks osaks peod, mistõttu polnud tal piisavalt aega õppimisele pühenduda.

Mingid kokkusaamised ja üksteise aitamised vist olid seal [kursusekaaslastega], aga mina nagu ei käinud. Mul olid peod, peod, peod! (V3)

\section{Arutelu}

Kõrgkoolide IKT erialadel katkestavad paljud üliõpilased oma õpingud juba esimesel õppeaastal ja seda otsust mõjutavad mitmed tegurid. Eesti üliõpilaste seas tehtud kvalitatiivse uuringu eesmärk oli mõista sügavamalt erinevusi väljalangenud ja edasiõppivate üliõpilaste vahel ning leida viise, kuidas väljalangemist vähendada. Uurimuse aluseks võeti Tinto (1993) 
integratsioonimudelis välja toodud tunnused, mille sobivust väljalangemise uurimiseks kinnitavad ka varasemad uurimused. IKT erialade kohta uuringu korraldamine oli oluline, sest IKT erialadel on suurem väljalangemus kui teistel erialadel ning valdkond ise on üsna uus ja kiiresti arenev.

\section{IKT erialade üliõpilasi iseloomustavad tunnused}

Esimene uurimisküsimus oli „Mis tunnused iseloomustavad IKT erialadel esimesel aastal õpingud katkestanud ja mittekatkestanud üliõpilasi?“. Esimese uurimisküsimuse puhul olid vaatluse all järgmised tunnused: õppija varasemad kogemused, eesmärgid, pühendumine ning akadeemiline ja sotsiaalne integratsioon. Järgnevalt on arutletud nende tunnuste üle esimesel aastal õppivate ja seejärel välja langenud üliõpilaste näitel.

Varasemate kogemuste analüüsist selgus, et koolis läbitud arvutiõpetuse või informaatikatunnid olid IKT üliõpilaste jaoks liiga üldised, kuid iseseisev IKT õppimine enne kõrgkooli muutis õpingud kõrgkoolis lihtsamaks. Üliõpilaste ootused eriala suhtes olid erinevad, sest nad tutvusid endi sõnul õppekavaga enne kõrgkooli astumist pinnapealselt ning saadud info oli neile raskesti arusaadav.

Õpingutele pühendumist võib segada õpingute ajal töötamine - see ilmnes ka mitme uuringus osalenud IKT üliõpilase vastustest. Õpingute ajal töötamine võib varasemate uuringute põhjal olla üks põhjuseid, miks üliõpilased õpingud katkestavad (Järve et al., 2015; Polidano \& Zakirova, 2011). Uuringus osalenud IKT üliõpilaste jaoks oli töökogemus olulisem kui kõrghariduskraad. Sellele, et üliõpilased väärtustavad praktilist oskust, on osutanud ka Altin ja Rantsus (2015). Lisaks on uuringud näidanud, et IKT valdkonna tööturul nõutakse kõrghariduskraadi järjest vähem (Järve et al., 2015). Kui tööturul kõrghariduskraadi ei nõuta, siis muutub see ka vähem oluliseks üliõpilaste jaoks. Selline negatiivne hoiak võib aga suurendada lõhet üliõpilase ja akadeemilise elu vahel ning ka ülikoolist väljalangemise tõenäosust (Must, Must, \& Täht, 2015).

Akadeemilise integratsiooniga seoses leidsid üliõpilased, et keeruliste õppeainete puhul ei ole loeng kõige tõhusam meetod õppesisu omandamiseks. Uuringud on näidanud, et loengus on üliõpilasel passiivne roll ja ta ei pruugi aru saada, miks on konkreetne õppeaine oluline (Espenberg et al., 2014). Sotsiaalse integratsiooniga seoses selgus intervjuudest, et eelisseisus on päevase õppe üliõpilased, sest õhtuse ja kaugõppe üliõpilased veedavad vähem aega koos kursusekaaslaste ja õppejõududega. Siiski tahaksid üliõpilased laiemaid valikuvõimalusi IKT õppimiseks kaugõppes, et õpingute kõrvalt saaks ka tööl käia. Praegu on Eestis IKT eriala kaugõppes võimalik 
õppida vaid ühes kõrgkoolis, kuid mitmetes uurimustes on osutatud, et õppevormide mitmekesistamine ka teistes kõrgkoolides tuleks kasuks (Järve et al., 2015).

\section{Erinevused õppivate ja väljalangenud üliõpilaste vahel}

Teine uurimisküsimus oli „Mille poolest erinevad IKT erialadel esimesel aastal õpingud katkestanud üliõpilased mittekatkestanud üliõpilastest?“. Kuna osa üliópilasi katkestab oma õpingud ja teine osa jätkab õpinguid, siis eeldati, et üliõpilaste esimese aasta kogemused kõrgkoolis võivad olla erinevad. Teise uurimisküsimuse vastuseks aga saadi, et õppivad ja väljalangenud IKT-üliõpilased erinevad vaid akadeemilise integratsiooni poolest. Erinevus seisnes selles, mis õppeaineid pidasid üliõpilased keeruliseks. Õpingud katkestanud üliõpilased nimetasid peamiselt keerulisi programmeerimisaineid, kuid õpinguid jätkanud üliõpilaste arvates olid keerulised pigem loogika ja matemaatikaga seotud õppeained. Ka kirjandusest leiab väiteid, et just programmeerimine (Watson \& Li, 2014) ja matemaatika (Divjak et al., 2010) on IKT-üliõpilaste jaoks keerulised. Sissejuhatavate õppeainete keerukus võib vähendada üliõpilaste soovi õpinguid jätkata (Baker et al., 2009) ning on ka IKT erialade puhul üks väljalangemise põhjuseid. Lisaks leidsid nii väljalangenud kui ka õpinguid jätkanud üliõpilased, et õpingud ei vastanud nende esialgsetele ootustele, kuid erinevus seisnes selles, et õpinguid jätkanud üliõpilased suutsid õpingutega kohaneda ja nende edasised ootused õpingute suhtes muutusid. Õpingute mittevastamine ootustele on ka varasemate uurimuste põhjal oluline põhjus, miks kõrgkoolist välja langetakse (Foster et al., 2012; Järve et al., 2015).

Kuigi erinevusi õpinguid katkestanud ja mittekatkestanud üliõpilaste vahel oli vähe, ilmnes oodatust rohkem erinevusi eri õppevormides (päevane, õhtune, kaugõpe) õppivate üliõpilaste vahel. Näiteks kui päevase õppe üliõpilased oli IKTd varem koolis õppinud, siis õhtuse ja kaugõppe üliõpilased olid IKT-kogemuse saanud tööl ning see innustas neid õppima IKTd kõrgkoolis. Samuti olid kaugõppe üliõpilased õppekava rohkem uurinud, et leida endale sobiv õppevorm. Ka töötavaid üliõpilasi oli õhtuse ja kaugõppe üliõpilaste seas rohkem. Varasemate uurimuste põhjal võtab aga töötamine palju õppimisaega ära ja võib põhjustada kõrgkoolist väljalangemist (Taylor et al., 2012). Seega on suuremas väljalangemisohus õhtuses ja kaugõppes õppivad üliõpilased.

Lisaks näitavad uurimistulemused, et sotsiaalse integratsiooni poolest on eelisseisus päevase õppe üliõpilased, sest nemad veedavad õhtuse ja kaugõppe üliõpilastest rohkem aega koos kursusekaaslaste ja õppejõududega. 
Ka teiste uuringute põhjal on kaugõppe puudusena nimetatud üliõpilaste motivatsiooni vähenemist, mis tuleneb vähestest kohtumistest kaasõppijate ja õppejõududega, ning kõrgkoolipoolse toetuse puudumist (Galusha, 1998). Vastukaaluks on aga Bean ja Metzner (1985) leidnud, et ebatraditsiooniliste (nt õhtuses ja kaugõppes õppivate) üliõpilaste puhul ei ole sotsiaalne integratsioon kõrgkoolis nii oluline kui traditsiooniliste üliõpilaste puhul. Ebatraditsiooniliste üliõpilaste jaoks on olulisemad kõrgkoolivälised suhted, näiteks sõprade ja pere toetus. Praeguste uurimistulemuste põhjal vajab õppevormide erinevus IKT erialadel edasist uurimist, et leida eri õppevormides õppivate üliõpilaste toetamiseks sobivad sekkumismeetmed.

\section{Soovitused väljalangemuse vähendamiseks}

Kolmas uurimisküsimus oli „Kuidas saaks üliõpilaste arvates vähendada väljalangemist IKT erialadelt?". Selle küsimuse vastuseks andsid uuringus osalenud IKT-üliõpilased ja esimesel aastal välja langenud üliõpilased mitmeid soovitusi, millele leiab kinnitust ka teaduskirjandusest. Näiteks selgus üliõpilaste vastustest, et neid peaks õppekava teemal rohkem informeerima juba enne õpingute algust. Sarnase soovituse on esitanud ka Järve jt (2015): üliõpilasi peaks erialaselt rohkem informeerima ning kõrgkoolid võiksid pakkuda sisseastujatele nõustamisteenust, et toetada õige eriala valikut. Uue ideena soovitasid IKT-üliõpilased teha sisseastujatega vestlused või testid, mis aitaksid välja selgitada tulevaste üliõpilaste motivatsiooni ja ka varasemaid teadmisi IKT valdkonnast. Lisaks võib IKT-üliõpilaste vastustest soovitusena välja tuua, et arvutiõpetuse või informaatikatundide sisu võiks olla üldhariduskoolides ühtlustatud, et kõrgkooli astuksid sarnaste eelteadmistega üliõpilased. Samamoodi on varasemate uuringute põhjal (nt Mis saab Eesti ..., 2015) soovitatud, et üliõpilaste eelteadmiste võrdsustamiseks oleks vaja üldhariduskoolidesse ühtseid õppematerjale ja koolitatud informaatikaõpetajaid.

Kaugõppe võimalusi on Eestis IKT valdkonnas praegu vähe ja neid võiks uuringus osalenud IKT-üliõpilaste arvates olla rohkem. Kaugõpe võimaldab üliõpilasel õpingute kõrvalt tööl käia, mis on IKT-üliõpilaste jaoks oluline. Samas selgus uuringust, et kaugõppe üliõpilastel on nõrgem sotsiaalne integratsioon kui päevase õppe üliõpilastel ning seetõttu vajavad nad õpingute lõpetamiseks rohkem toetust. See tähendab, et kõrgkoolidele, kus pakutakse kaugõppe võimalusi, võiks soovitada kaugõppe eripära arvestava toetussüsteemi väljatöötamist.

Nii kaugõppes kui ka päevases õppes on palju üliõpilasi, kes töötavad. Praeguse uurimuse tulemuste põhjal võib soovitada kõrgkoolidel pakkuda 
üliõpilastele rohkem võimalusi töökogemuse arvestamiseks. Seda võiks teha näiteks VÕTA (varasemate õpingute ja töökogemuse arvestamise) süsteemi kasutades. Õppekavadest leiab kindlasti selliseid õpiväljundeid, mida saaks saavutada ka teatud töökohtadel, ning neid võimalusi võiks üliõpilastele ja tööandjatele rohkem pakkuda. Nii võiks näiteks üliõpilasel, kes töötab programmeerijana, minna VÕTA süsteemi kaudu arvesse teatud hulk programmeerimisega seotud õppeaineid. Iga töötav üliõpilane võiks koostöös kõrgkooli ja tööandjaga välja töötada plaani, mille järgi ta saaks õppimise ja töötamise paremini kooskõlla viia. See tähendab, et kõrgkool peaks tegema rohkem koostööd tööandjatega ning ka õppeained võiksid olla kohandatavad töötavatele üliõpilastele.

Lisaks on leitud, et väljalangemist aitaks ennetada tugiteenuste (tuutorite, mentorite) võimaldamine üliõpilastele (Järve et al., 2015). Vajadus tugiteenuste järele ilmnes ka praeguses uuringus osalenud IKTüliõpilaste vastustest. Kõige rohkem oli üliõpilastel probleeme matemaatika ja programmeerimisega seotud õppeainetes, mistõttu peaksid kõrgkoolid tuutorite ja mentorite tuge pakkuma just eelkõige nendes ainetes. Keeruliste õppeainete õppimise teeks üliõpilaste jaoks lihtsamaks ka see, kui õppejõududel oleks paremad pedagoogilised oskused. See läheb kokku Järve jt (2015) esitatud soovitusega, et õppejõudude pedagoogilised oskused vajavad täiendamist ning rohkem võiks kõrgkoolis kasutada aktiiv- ja probleemõpet (Järve et al., 2015; Mets \& Leoma, 2016). Uue soovitusena tõid IKT-üliõpilased ka välja, et üliõpilased võiksid olla õppetöös jagatud tasemete järgi rühmadesse, sest see aitaks neil õpingutega paremini toime tulla. Nii saaks näiteks varasema programmeerimiskogemusega üliõpilased õppida kiiremas tempos ja programmeerimisega esimest korda kokku puutuvad üliõpilased rahulikumas tempos.

Siiski tuleb tulemuste tõlgendamisel arvestada uurimuse piirangutega. Esiteks oli uurimuse valim üsna väike. Teiseks polnud valim esinduslik, sest vastajate hulgas oli rohkem naissoost üliõpilasi kui IKT valdkonnas keskmiselt. Samuti oli vastajate keskmine vanus kõrgem kui IKT-üliõpilastel üldiselt, mistõttu võivad vastajad olla rohkem kogenud ja kogemuste tõttu õpingute suhtes kriitilisemad. Lisaks kasutati andmete analüüsimisel induktiivset sisuanalüüsi ja paigutati sel viisil leitud kategooriad Tinto (1993) mudelis toodud kategooriate alla, et esitada tulemusi süsteemsemalt. Tinto (1993) mudelit ei kasutatud kohe andmete analüüsimisel, sest sooviti sügavamalt mõista üliõpilaste vastuseid ja tõlgendusi. 


\section{Kokkuvõte}

Artiklis anti ülevaade teguritest, mis on Tinto (1993) integratsioonimudeli järgi kõrgkoolide IKT erialadel esimesel aastal óppimise ja väljalangemise seisukohast olulised. Varem pole neid tegureid IKT erialade kontekstis autoritele teadaolevalt uuritud. Kuigi uurimus põhineb Eesti kõrgkoolide näitel, võiksid tulemused huvi pakkuda ka mujal maailmas, sest probleemid väljalangemisega IKT erialadelt esinevad mujalgi (nt Divjak et al., 2010; Heublein, 2014) ning IKT-oskustega töötajate puudujääk Euroopa Liidus vajab lahendust. Lisaks saab uurimistulemusi rakendada IKTga mitteseotud õppekavadel, kus on samuti probleeme suure väljalangemusega.

Kvalitatiivne lähenemisviis võimaldas märgata, et noori tuleks õige eriala leidmisel toetada juba üldhariduskoolis. Lisaks vajavad üliõpilased kõrgkoolis õppides mitmesugust toetust ning paindlikke õppetingimusi, et saada hakkama keeruliste õppeainete ja õpingute ajal töötamisega. Uurimistulemused näitavad, et väljalangenud ja edasiõppivad üliõpilased ei erine Tinto (1993) mudelis esitatud tunnuste poolest üksteisest palju. Nii seisneb uurimuse olulisus just selles, et Tinto (1993) mudel sobib kvalitatiivse uurimismeetodi korral ka IKT-üliõpilaste integratsiooni kirjeldamiseks. Edasi oleks vaja uurida, miks ikkagi osa üliõpilasi otsustab õpingud pooleli jätta ja osa mitte. IKT-üliõpilased esitasid küll mitmeid soovitusi, mida saaks kõrgkoolides väljalangemuse vähendamiseks rakendada, kuid vajalikud oleksid edasised uuringud, et leida, kuidas need soovitused praktikas töötavad ning kuidas peaks üliõpilaste toetamisel arvestama nende õppevormiga.

\section{Tänusõnad}

Uurimust on toetanud Euroopa Liit Euroopa regionaalarengu fondi kaudu, mis finantseeris projekti „Kontseptuaalne raamistik suurendamaks ühiskonna pühendumist IKTsse: IKTga seonduvaid karjäärivalikuid motiveerivad ning IKT rakendamiseks ja arendamiseks vajalikku kompetentsust arendavad lähenemised üld- ja kõrghariduses“.

\section{Kasutatud kirjandus}

Altin, H., \& Rantsus, R. (2015). Why students fail to graduate ICT-related curricula at university level. In L. Gómez Chova, A. López Martínez, \& I. Candel Torres (Eds.), INTED2015 Proceedings (pp. 5364-5368). Madrid: IATED Academy. 
Baker, L. J., McDowell, C., \& Kalahar, K. (2009). Exploring factors that influence computer science introductory course students to persist in the major. Proceedings of the 40th ACM technical symposium on computer science education (pp. 153157). New York: ACM.

Bean, J. P. (1985). Interaction effects based on class level in an explanatory model of college student dropout syndrome. American Educational Research Journal, 22(1), 35-64. https://doi.org/10.3102/00028312022001035

Bean, J. P., \& Metzner, B. S. (1985). A conceptual model of nontraditional undergraduate student attrition. Review of Educational Research, 55(4), 485-540. https://doi.org/10.3102/00346543055004485

Belloc, F., Maruotti, A., \& Petrella, L. (2011). How individual characteristics affect university students drop-out: A semiparametric mixed-effects model for an Italian case study. Journal of Applied Statistics, 38(10), 2225-2239. https://doi.org/10.1080/02664763.2010.545373

Cabrera, A. F., Nora, A., \& Castaneda, M. B. (1993). College persistence: Structural equations modeling test of an integrated model of student retention. The Journal of Higher Education, 64(2), 123-139. https://doi.org/10.2307/2960026

Chen, R. (2012). Institutional characteristics and college student dropout risks: A multilevel event history analysis. Research in Higher Education, 53(5), 487-505. https://doi.org/10.1007/s11162-011-9241-4

Cohen, J. (1960). A coefficient of agreement for nominal scales. Educational and Psychological Measurement, 20(1), 37-46. https://doi.org/10.1177/001316446002000104

Divjak, B., Ostroski, M., \& Hains, V. V. (2010). Sustainable student retention and gender issues in mathematics for ICT study. International Journal of Mathematical Education in Science and Technology, 41(3), 293-310. https://doi.org/10.1080/00207390903398416

Duque, L. C. (2014). A framework for analysing higher education performance: Students' satisfaction, perceived learning outcomes, and dropout intentions. Total Quality Management \& Business Excellence, 25(1-2), 1-21. https://doi.org/10.1080/14783363.2013.807677

Eesti Hariduse Infosüsteem (EHIS) (2015). Külastatud aadressil http://www.ehis.ee/. Espenberg, K., Aksen, M., Beilmann, M., Vahaste, S., Loogus, T., \& Kührt, U. (2014). Kõrgkooliõpingute katkestamise põhjused ja ennetamise võimalused Euroopa Liidu riikide näitel. Lõpparuanne. Tartu: Tartu Ülikooli sotsiaalteaduslike rakendusuuringute keskus RAKE.

Foster, E., Lawther, S., Keenan, C., Bates, N., Colley, B., \& Lefever, R. (2012). The HERE Project: Higher education: Retention \& engagement. London: Paul Hamlyn Foundation. Retrieved from http://www.improvingthestudentexperience.com/ library/UG_documents/Final_Report_-_HERE_Project.pdf.

Galusha, J. M. (1998). Barriers to learning in distance education. University of Southern Mississippi.

Gareis, K., Hüsing, T., Birov, S., Bludova, I., Schulz, C., \& Korte, W. B. (2014). E-skills for jobs in Europe: Measuring progress and moving ahead (Final report). Bonn: Empirica. Retrieved from http://eskills-monitor2013.eu/fileadmin/monitor2013/ documents/monitor_final_report.pdf. 
Hagan, H., \& Markham, S. (2000). Does it help to have some programming experience before beginning a computing degree program? Proceedings of the 5th annual SIGCSE/SIGCUE ITiCSE conference on innovation and technology in computer science education (pp. 25-28). Helsinki: ACM. https://doi.org/10.1145/343048.343063

Heublein, U. (2014). Student drop-out from German higher education institutions. European Journal of Education, 49(4), 497-513.

https://doi.org/10.1111/ejed.12097

Hurtado, S., \& Carter, D. F. (1997). Effects of college transition and perceptions of the campus racial climate on Latino students' sense of belonging. Sociology of Education, 70(4), 324-345. https://doi.org/10.2307/2673270

Hüsing, T., Korte, W. B., Fonstad, N., Lanvin B., Cattaneo, G., Kolding, M., ... van Welsum, D. (2013). e-Leadership: e-Skills for competitiveness and innovation vision, roadmap and foresight scenarios (Final report). Retrieved from http://eskills-vision.eu/fileadmin/eSkillsVision/documents/VISION\%20Final\%20 Report.pdf.

Järve, J., Kallaste, E., \& Räis, M. L. (2015). Tudengite õpingute katkestamise põhjused IKT kõrghariduses. Tallinn: Eesti Rakendusuuringute Keskus Centar. Külastatud aadressil http://www.centar.ee/uus/wp-content/uploads/2015/07/IKT-katkestajate-uuringu-1\%C3\%B5ppraport-veebi.pdf.

Jürgenson, A., Mägi, E., Pihor, K., Batueva, V., Rozeik, H., \& Arukaevu, R. (2013). Eesti IKT kompetentsidega tööjõu hetkeseisu ja vajaduse kaardistamine. Tallinn: Poliitikauuringute Keskus Praxis.

Kori, K., Altin, H., Pedaste, M., Palts, T., \& Tõnisson, E. (2014). What influences students to study information and communication technology? In L. Gómez Chova, A. López Martínez, \& I. Candel Torres (Eds.), INTED2014 Proceedings (pp. 14771486). IATED Academy.

Kori, K., Pedaste, M., Leijen, Ä., \& Tõnisson, E. (2016). The role of programming experience in ICT students' learning motivation and academic achievement. International Journal of Information and Education Technology, 6(5), 331-337. https://doi.org/10.7763/IJIET.2016.V6.709

Kori, K., Pedaste, M., Niitsoo, M., Kuusik, R., Altin, H., Tõnisson, E., ... \& Paluoja, R. (2015). Why do students choose to study information and communications technology? Procedia - Social and Behavioral Sciences, 191, 2867-2872. https://doi.org/10.1016/j.sbspro.2015.04.249

Landis, J. R., \& Koch, G. G. (1977). The measurement of observer agreement for categorical data. Biometrics, 33(1), 159-174. https://doi.org/10.2307/2529310

Larsen, M. S., Kornbeck, K. P., Kristensen, R. M., Larsen, M. R., \& Sommersel, H. B. (2013). Dropout phenomena at universities: What is dropout? Why does dropout occur? What can be done by universities to prevent or reduce it? A systematic review. Copenhagen: Danish Clearinghouse for Educational Research. Retrieved from http://edu.au.dk/fileadmin/edu/Udgivelser/Clearinghouse/Review/Evidence_on_ dropout_from_universities_technical_report_May_2013.pdf.

Lassibille, G., \& Gómez, L. N. (2008). Why do higher education students drop out? Evidence from Spain. Education Economics, 16(1), 89-105.

https://doi.org/10.1080/09645290701523267 
Long, M., Ferrier, F., \& Heagney, M. (2006). Stay, play or give it away? Students continuing, changing or leaving university study in first year. Clayton: ACER-CEET.

Mets, U., \& Leoma, R. (2016). Tulevikuvaade tööjõu- ja oskuste vajadusele: info- ja kommunikatsioonitehnoloogia. Uuringu terviktekst. Külastatud aadressil http://oska.kutsekoda.ee/wp-content/uploads/2016/04/IKT-Raport-loplik.pdf.

Mis saab Eesti IT haridusest? Kes tuleb õppima? Kes kuidas õpib? Kes langeb välja? Mida saab keegi teha? Raport (2015). Külastatud aadressil https://sisu.ut.ee/sites/default/files/ikt/files/iktraport_31.08.2015.pdf.

Must, O., Must, A., \& Täht, K. (2015). Programmi TULE uuringu „Haridustee valikud ning ópingute katkestamise asjaolud Eesti kõrghariduses“ aruanne. Tartu: Tartu Ülikooli psühholoogia instituut. Külastatud aadressil http://dspace.ut.ee/handle/10062/49551.

OECD (2013). Education at a glance 2013: OECD indicators. OECD Publishing. Retrieved from https://www.oecd.org/edu/eag2013\%20(eng)--FINAL\%2020\%20 June\%202013.pdf.

Polidano, C., \& Zakirova, R. (2011). Outcomes from combining work and tertiary study. A national vocational education and training research and evaluation program report. Adelaide: National Centre for Vocational Education Research.

Stratton, L. S., O’Toole, D. M., \& Wetzel, J. N. (2008). A multinomial logit model of college stopout and dropout behavior. Economics of Education Review, 27(3), 319331. https://doi.org/10.1016/j.econedurev.2007.04.003

Taylor, G., Lekes, N., Gagnon, H., Kwan, L., \& Koestner, R. (2012). Need satisfaction, work-school interference and school dropout: An application of self-determination theory. British Journal of Educational Psychology, 82(4), 622-646. https://doi.org/10.1111/j.2044-8279.2011.02050.x

Terenzini, P. T., \& Pascarella, E. T. (1980). Toward the validation of Tinto's model of college student attrition: A review of recent studies. Research in Higher Education, 12(3), 271-282. https://doi.org/10.1007/BF00976097

Tinto, V. (1975). Dropout from higher education: A theoretical synthesis of recent research. Review of Educational Research, 45(1), 89-125. https://doi.org/10.3102/00346543045001089

Tinto, V. (1993). Leaving college: Rethinking the causes and cures of student attrition (2nd ed.). Chicago: University of Chicago Press.

Tinto, V. (2006). Research and practice of student retention: what next? Journal of College Student Retention: Research, Theory \& Practice, 8(1), 1-19. https://doi.org/10.2190/4YNU-4TMB-22DJ-AN4W

Watson, C., \& Li, F. W. B. (2014). Failure rates in introductory programming revisited. Proceedings of the 2014 conference on innovation \& technology in computer science education (pp. 39-44). New York: ACM. https://doi.org/10.1145/2591708.2591749

Wolter, S. C., Diem, A., \& Messer, D. (2014). Drop-outs from Swiss universities: An empirical analysis of data on all students between 1975 and 2008. European Journal of Education, 49(4), 471-483. https://doi.org/10.1111/ejed.12096 
Lisa 1. Intervjuu kava

Õppivate üliõpilaste jaoks muudetud küsimused on tähistatud sulgudes kaldkirjas. Küsimused, mida õppivatelt üliõpilastelt üldse ei küsitud, on alla joonitud.

1. Nimi, vanus, sugu, gümnaasium

2. Kõrgkool, eriala

3. Millal jätsite õpingud pooleli?

4. $\quad$ Mis oli peamiseks õpingute katkestamise põhjuseks?

5. Kas vahetasite elukohta kõrgkooli astudes?

6. Kuidas mõjutas elukoha vahetus õpinguid kõrgkoolis?

7. Milliste eesmärkidega astusite kõrgkooli ning millised olid ootused valitud eriala suhtes?

8. Millisel määral tutvusite eelnevalt õppekavaga?

9. Mil määral vastasid õpingud Teie ootustele? (Mil määral on ópingud vastanud algsetele ootustele?)

10. Kas katkestamise põhjuseks oli õpingute mittevastamine ootustele?

11. Milline oli Teie varasem kokkupuude IKTga?

a. Kas osalesite kooli ajal arvutiõpetuse või informaatikatundides?

b. Kui kaua kestsid need õpingud?

c. Milline oli arvutiópetuse või informaatikatundide aineprogramm?

d. Kuidas varasem kokkupuude IKTga aitas kõrgkooliõpingutele kaasa?

e. Kas varem olete teinud mingit tööd IKT valdkonnas?

12. Millega tegelete praegu (eriala vahetus / töö)?

a. Kas käisite (käite) õpingute kõrvalt tööl?

b. Mis põhjustel käisite (käite) õpingute kõrvalt tööl?

c. Kuidas leidsite erialase töökoha?

d. Kuidas suhtus ( $\underline{\text { suhtub}}$ ) tööandja õpingute ajal töötamisse? (toetas (toetab) / ei toetanud (ei toeta) õppimist)

e. Kui suure koormusega töötasite (töötate)? (osakoormusega/täiskoormusega)

f. Kas diplom oleks mingit rolli mänginud (võiks mingit rolli mängida) tööle minemisel? (diplom huvitas (huvitaks) / ei huvitanud (huvitaks) tööandjat; palganumber sõltus (sõltuks) / ei sõltunud (sõltuks) diplomist)

g. Kas töötate erialasel töökohal ja mis on Teie peamised tööülesanded?

h. Kui vahetasite eriala, siis mida Te õppima asusite?

13. Kas saite (saate / olete saanud) õpingute ajal erialastipendiumi või muid toetuseid?

a. Kui suur oli (on) saadav stipendium?

b. Kas saadav stipendium oli (on) Teie jaoks piisav?

c. Kas selleta oleksite õpingud katkestanud varem?

d. Kui oleksite saanud stipendiumi, kas oleksite jätkanud õpinguid? (Kui saaksite stipendiumi, kas see mõjutaks Teie õppima jäämist?)

e. Kuidas mõjutas (mõjutab) stipendiumi saamine või mittesaamine Teie õpinguteaegset majanduslikku olukorda?

f. Kui suur peaks olema stipendium, et tudeng saaks piisavalt õpingutele pühenduda ja lõpetada nominaalajaga? 
14. Kas ja millised kõrgkoolis õpetatavad alusained tekitasid (tekitavad) enim probleeme?

15. Kas ja mis valmistas kõrgkoolis õpingute ajal veel raskusi? (Kas ja milliseid probleeme on esinenud õppimisel?)

16. Kas katkestamise põhjuseks olid probleemid õppimisega?

17. Millised olid (on) Teie suhted õppejõududega?

18. Millised olid (on) Teie suhted kaastudengitega?

19. Millised õppejõudude kasutatud õppemeetoditest sobisid (sobivad) Teile õpingute ajal kõige rohkem?

20. Millised kasutatud õppemeetoditest valmistasid (valmistavad) Teile raskusi ja miks?

21. Millistel tingimustel oleksite nõus tagasi tulema ja lõpetama sama eriala?

22. Mis kasu/kahju saite (olete saanud) kõrgkoolis veedetud ajast?

23. Millist kasu tooks õpingute lõpetamine IKT valdkonnas?

24. Mida võiks sel erialal muuta, et vähendada väljalangejate arvu? 


\title{
First-year higher education ICT studies and dropout rates - the Estonian case
}

\author{
Külli Kori ${ }^{\text {al }}$, Kadri Mardo \\ ${ }^{a}$ Institute of Education, University of Tartu \\ ${ }^{b}$ Tartu Catholic Education Centre
}

\section{Summary}

\section{Introduction}

The importance of information and communication technology (ICT) has undergone a significant growth in the past decades. The labour market therefore needs more workers with ICT knowledge and skills, especially in the fields of science and technology (Gareis et al., 2014). According to forecasts, by the year 2020 the unmet demand for ICT practitioners in the European Union could rise from 481,000 to 1,685,000 (Hüsing et al., 2013). In Estonia, a need for 6661-8456 additional ICT workers is predicted by 2020 (Hüsing et al., 2013). However, if the current numbers of students enrolling in higher education ICT curricula are sustained, the demand of the Estonian labour market will be met. But, we are facing another problem in higher education, which may still lead to an insufficient number of ICT workers - high dropout rates.

Dropout is a global problem, and ICT is not the only field affected. Nevertheless, STEM fields (36\%-39\%), which also include ICT, exhibit the highest dropout rates (Heublein, 2014). The average European higher education dropout rate is 19\% in the ICT field (Hüsing et al., 2013), but in Estonia about two thirds of undergraduate IT students fail to finish their studies (authors' calculations based on the Estonian Education Information System (EHIS), 2015). This far exceeds the average European dropout rate in IT and surpasses other fields of study in Estonia.

One of the most often used dropout models is the one developed by Vincent Tinto. Tinto's (1993) complex model of students' departure shows the following aspects to be an important influence on their decision to drop out: pre-entry attributes (family background, skills and abilities, prior schooling), goals and commitments, as well as academic and social interaction. However, only a few studies have been conducted regarding the 
problem of dropout in the ICT field. Tinto's (1993) model is applied to this study.

The current study, based on the Estonian case, investigated first-year student ICT studies and their reasons for dropping out, and, in particular, the differences between students who drop out and those who do not. We also collected ideas from both dropouts and those who continued studying, as to what could be done to prevent dropout. The following research questions were formulated:

1) What characterises first year ICT students and dropouts?

2) How do first year ICT students and dropouts differ from each other?

3) What can be done to reduce dropout rates in the ICT field?

\section{Methodology}

Qualitative research methods were used in the current study. The sample consisted of 16 ICT students who started their studies in 2014 at two higher education institutions in Estonia. Of the 16 students, 8 dropped out during the first year and 8 continued their studies in the second year. The students were studying in different study forms: full-time studies, evening studies and distance learning.

Data was collected through semi-structured interviews. The questions in the questionnaires and interviews were formed on the basis of Tinto's (1993) model. Thus, the questions were about students' pre-entry attributes (especially about prior experiences), goals for studying ICT, commitments to ICT studies, and academic and social integration.

Grounded theory was used to analyse the qualitative data. Two raters categorised the interviews and Cohen's kappa was calculated. The Cohen's kappa coefficient was 0.8 , showing good inter-rater reliability (Landis \& Koch, 1977).

\section{Results and conclusions}

The current research was based on Tinto's (1993) model of dropout which concluded the following student characteristics: pre-entry attributes, goals for studying ICT, commitments to ICT studies, and academic and social integration. Whereas the study focused on Estonia, the results could also be of interest to other countries, as the problem of dropout exists globally (e.g., Divjak et al., 2010; Heublein, 2014). 
Concerning the first research question, the students were shown to have different prior experiences before entering university. Prior programming experience has been found to be useful for ICT students (Hagan \& Markham, 2000; Kori et al., 2016), but the students who had learned ICT at a general education level did not find the knowledge to be useful at university. Students also had different goals for studying ICT at university, but only a few had sufficient information about the curriculum. It has been found that as curriculum introductions on universities' websites are quite short and not very informative, students may have unrealistic expectations for their studies (Espenberg et al., 2014). In addition, many of the ICT students were working during their studies to earn money and acquire some work experience that gives them an important advantage in the labour market. Working, however, is also one of the reasons why students are unable to sufficiently commit to their studies - and this, in turn, may lead to dropout (Järve et al., 2015; Polidano \& Zakirova, 2011).

Some problems with academic integration were detected - certain courses and lecturers caused difficulties for the ICT students. A lecture is normally one of the main methods of teaching in the first study year (Espenberg et al., 2014), but students did not find this method effective. Mass lectures also fail to facilitate social integration. However, social integration is an important feature to avoid student dropout (Chen, 2012; Duque, 2014).

In the second research question, fewer differences than expected were detected in the answers from dropouts and of those students who continued their studies. As to academic integration, dropouts were found to have problems with programming courses - a finding that is also supported by the literature (Watson \& $\mathrm{Li}, 2014$ ). The students who continued their studies encountered some problems with logic, algorithms and mathematics related courses, but still conceded that such courses gave them a valuable understanding and knowledge that is required to pass the following courses. Otherwise, the answers of the two groups (dropouts and students who continued studying) were quite similar.

More substantial differences appeared in different study forms. Students in full-time studies had prior experience in ICT from school, whereas those in evening studies and distance learning had gained ICT experience in their workplace, which had motivated them to enrol in ICT studies. Also, social integration was weaker in students of evening studies and distance learning, as they did not meet the lecturers and other students as often as those who were studying full-time. Other studies have also pointed out the negative side of this type of study form - lack of social integration may cause a drop in students' study motivation (Galusha, 1998). 
The third research question resulted in some recommendations by the participants of this study, which, in fact, have also been suggested in other studies. For example, the students pointed out that they should be more realistically informed about the curriculum before starting their undergraduate ICT studies. A similar recommendation has been made by Järve et al. (2015) who also proposed that universities should offer counselling to students in order for them to make a good career choice. The ICT students also felt that informatics classes in different general schools should be more harmonised so that university students have more homogenous prior knowledge. Similarly, another study has highlighted the need for general informatics learning materials and teacher training (Mis saab Eesti ..., 2015). Another suggestion by the ICT students was more distance learning opportunities. Distance learning in ICT is currently offered by only one higher education institution in Estonia; however, working students need more flexible study forms (Järve et al., 2015).

In conclusion, students need support at the general education level to make the right career choice and to enrol in the most suitable curriculum. During higher education studies, support and more flexible study conditions are necessary for students to cope with difficult courses and working. Although the ICT students made some theoretical recommendations in the current study, more research is needed to determine the help required to reduce dropout rates in practice.

Keywords: ICT, higher education, dropout 